Vol. 11 No. 012020

e-issn : 2622-0148, p-issn : 2087-0035

\title{
HUBUNGAN LAMA KERJA PER HARI DENGAN KEJADIAN LOW BACK PAIN PADA PENGRAJIN SANGGAH (PASIR HITAM) DI BANJAR SELAT TENGAH SUSUT BANGLI
}

Relationship Work Time Per Day with The Event of Low Back Pain in Sanggah Craftsmen (Black Sand) in Banjar Selat Tengah Susut Bangli

\author{
Ni Komang Parwati ${ }^{1}$ \\ ${ }^{1}$ STIKES Bina Usada Bali \\ *) kirana.ayu@yahoo.com
}

\begin{abstract}
Low back pain is pain that is felt in the lower back from the spinal region (lower back), muscles, nerves, tendons, joints, or cartilage. Many things can be done to reduce the occurrence of low back pain by changing one's work habits and getting enough rest. The purpose of this study is to determine the relationship of work duration per day with the incidence of low back pain in Sanggah (black sand) craftsmen. This study uses a non-probability sampling type Purposive Sampling with a quantitative method that is Observational using a cross sectional research design with a sample of 44 respondents who experienced Low Back Pain. The results of the analysis of the relationship between working hours per day with the occurrence of Low Back Pain using the Spearmen Rank Correlation test obtained the value of $p$ value $=0.047$. So it can be concluded that there is a relationship of work time per day with the occurrence of low back pain in Sanggah (black sand) craftsmen in Banjar Selat Tengah Susut Bangli.
\end{abstract}

Keywords: work time, low back pain, craftsmen

\section{ABSTRAK}

Low back pain adalah rasa nyeri yang dirasakan di bagian punggung bawah yang bersumber pada tulang belakang daerah spinal (punggung bawah), otot, saraf, tendon, sendi, atau tulang rawan. Banyak hal yang dapat dilakukan untuk mengurangi terjadinya low back pain dengan mengubah kebiasaan bekerja seseorang dan melakukan istirahat yang cukup. Adapun tujuan dari penelitian ini adalah untuk mengetahui hubungan lama kerja per hari dengan kejadian low back pain pada pengrajin sanggah (pasir hitam). Penelitian ini menggunakan Nonprobability Sampling jenis Purposive Sampling dengan metode Kuantitatif yaitu Observasional dengan menggunakan desain penelitian Cross Sectional dengan jumlah sampel 44 responden yang mengalami Low Back Pain. Adapun hasil analisis mengenai hubungan lama bekerja perhari dengan kejadian Low Back Pain yang menggunakan uji Korelasi Spearmen Rank didapatkan hasil nilai $p$ value $=0,047$. Sehingga dapat disimpulkan bahwa ada hubungan lama kerja per hari dengan kejadian low back pain pada pengrajin sanggah (pasir hitam) di Banjar Selat Tengah Susut Bangli.

Kata kunci: lama kerja, low back pain, pengrajin

\section{PENDAHULUAN}

Pelaku industri saat ini sebagian besar menggunakan mesin untuk mempermudah pekerjaannya, mulai dari mesin yang sederhana sampai mesin berbasis teknologi tinggi. Namun, beberapa industri masih melakukan pekerjaan secara konvensional. Akibat dari kerja secara konvensional yaitu terjadinya peningkatan keluhan pada pekerja seperti: terjadinya nyeri pada punggung dan pinggang, ketegangan pada leher, sakit pada pergelangan tangan, lengan dan kaki, kelelahan mata, dan keluhan lainnya (Tarwaka, 2010). Salah satu contoh pekerjaan yang dilakukan secara konvensional yaitu pengrajin sanggah pasir hitam atau sering disebut bias malela. Menurut Kamus Besar Bahasa Indonesia (KBBI) pengrajin merupakan seseorang yang bekerja untuk membuat barang kerajinan, sedangkan pengrajin ukiran merupakan orang yang pekerjaan atau aktivitas sehari-harinya menghasilkan barang-barang ukiran (Depdiknas, 2008).
Aktivitas sehari-hari yang menuntut banyak gerak kedepan maupun membungkuk, duduk maupun berdiri terlalu lama atau postur tubuh lain yang salah akan mengakibatkan nyeri pinggang non spesifik (Harianto, 2010). Nyeri merupakan suatu sensori subjektif dan pengalaman emosional yang tidak nyaman berkaitan dengan kerusakan jaringan yang aktual atau potensial yang dirasakan ketika terjadi kerusakan (Potter \& Perry, 2010). Nyeri punggung bawah merupakan penyakit yang tidak mengenal usia dapat menyerang usia muda maupun usia tua yang sering terjadi dalam kehidupan seharihari (Widyastoeti, 2009). Low Back Pain (LBP) merupakan rasa nyeri yang menyerang punggung bawah dengan gejala nyeri lokal, radikular, atau keduanya. Nyeri ini terasa pada lumbar atau lumbosakral dan sering disertai dengan nyeri ke arah tungkai dan kaki (Tanjung, 2009). Berdasarkan penelitian dari Safitri (2010), penyebab dari Low Back Pain yang paling banyak dijumpai yaitu disebabkan oleh duduk yang terlalu lama, sikap duduk yang 
Vol. 11 No. 012020

e-issn : 2622-0148, p-issn : 2087-0035

salah dan aktivitas yang terlalu berlebihan. Lamanya waktu bekerja dapat menyebabkan risiko terjadinya nyeri punggung bawah (Suma'mur, 2009). Posisi duduk baik tegak maupun membungkuk dalam jangka waktu lebih dari 30 menit dapat mengakibatkan gangguan pada otot (Risyanto, 2008).

Penelitian serupa yang dilakukan oleh Remon, Utami dan Dewi pada tahun 2015 mengenai hubungan antara posisi tubuh saat bekerja terhadap kejadian Low Back Pain pada petani sawit yang dilaksanakan di Kelurahan Kotalama. Penelitian ini membahas berapa umur petani sawit, lama masa kerja, jumlah sawit yang diangkat, gambaran posisi kerja saat bekerja terhadap kejadian low back pain. Hasil uji Chi-Square posisi tubuh dengan kejadian Low Back Pain diperoleh nilai $p$ value $0,000(p<0,05)$ yang menunjukkan bahwa ada hubungan yang signifikan antara posisi tubuh saat bekerja dengan kejadian Low Back Pain pada petani sawit.

Low Back Pain merupakan penyakit yang sering dijumpai dan menimbulkan banyak permasalahan. Dilihat dari data yang dikumpulkan dari penelitian Pusat Riset dan Pengembangan Pusat Ekologi Kesehatan, Departemen Kesehatan yang melibatkan 800 orang dari 8 sektor informal di Indonesia menunjukkan keluhan Low Back Pain dialami oleh 31,6\% petani kelapa sawit di Riau, 21\% pengrajin wayang kulit di Yogyakarta, 18\% pengrajin onix di Jawa Barat, $16 \%$ penambang emas di Kalimantan Barat, 14,9\% pengerajin sepatu di Bogor dan $8 \%$ pengrajin kuningan di Jawa Tengah. Selain itu, pengerajin batu bata di Lampung dan nelayan di DKI Jakarta yang menderita keluhan LBP masingmasing 76,7\% dan 41\% (Sakinah, 2013).

Peneliti telah melakukan studi pendahuluan yang dilakukan di Banjar Selat Tengah Susut Bangli didapat bahwa jumlah penduduk dari kepala keluarga di Banjar tersebut adalah berjumlah 206 KK dan terdapat 50 orang dari jumlah penduduk memiliki pekerjaan sebagai pengrajin sanggah (pasir hitam) atau sering disebut bias malela. Berdasarkan wawancara singkat yang dilakukan didapat bahwa lama bekerja pada pengrajin kurang lebih sekitar 8-9 jam per harinya keluhan yang paling sering dialami yaitu nyeri punggung bawah kurang lebih 10 pengrajin mengatakan terdapat delapan orang pengrajin nyeri pinggang yang disebabkan oleh posisi kerja yang berubah-ubah seperti duduk, jongkok, dan berdiri, dimana dari delapan orang tersebut dua orang yang mengalami nyeri berat, empat orang mengalami nyeri sedang, dua orang yang mengalami nyeri ringan, sehingga peneliti tertarik untuk mengetahui hubungan lama bekerja perhari dengan kejadian Low Back Pain pada pengrajin sanggah (pasir hitam) di Banjar Selat Tengah Susut Bangli.

\section{METODE}

Penelitian ini adalah penelitian kuantitatif yaitu observasional yang menggunakan desain penelitian cross sectional. Populasinya adalah seluruh pengrajin sanggah (pasir hitam) di Banjar Selat Tengah sebanyak 50 orang. Sampel dipilih sebanyak 44 pengrajin sanggah (pasir hitam) dengan cara purposive sampling menggunakan kriteria inklusi dan eksklusi. Deta analisis menggunakan analisis kolerasi spearmen rank.

\section{HASIL}

\section{Gambaran Karakteristik Subyek Penelitian Berdasarkan Usia}

Tabel 1. Karakteristik Subyek Penelitian Berdasarkan Usia

\begin{tabular}{cccccc}
\hline Variabel & N & Rerata & Min & Maks & SD \\
\hline Usia & 44 & 42,32 & 27 & 59 & 7,808 \\
\hline
\end{tabular}

Tabel 1 menunjukkan bahwa menunjukkan bahwa rata-rata usia responden adalah 42,32 tahun dengan usia tertinggi yaitu 59 tahun dan terendah 27 tahun.

\section{Gambaran Karakteristik Subyek Penelitian Berdasarkan Jenis Kelamin}

Tabel 2. Karakteristik Subyek Penelitian Berdasarkan Jenis Kelamin

\begin{tabular}{ccc}
\hline Kategori & Frekuensi & $\begin{array}{c}\text { Persentase } \\
(\%)\end{array}$ \\
\hline Laki-laki & 44 & 100 \\
\hline Perempuan & 0 & 0 \\
\hline Total & 44 & 100 \\
\hline
\end{tabular}

Tabel 2 menunjukkan bahwa seluruh responden berjenis kelamin laki-laki sebanyak 44 responden (100\%).

\section{Gambaran Karakteristik Subyek Penelitian Berdasarkan Lama Bekerja}

Tabel 3. Karakteristik Subyek Penelitian Berdasarkan Lama Bekerja

\begin{tabular}{ccc}
\hline Kategori & Frekuensi & $\begin{array}{c}\text { Persentase } \\
(\%)\end{array}$ \\
\hline$\leq 10$ Tahun & 28 & 63,6 \\
\hline$>10$ Tahun & 16 & 36,4 \\
\hline Total & 44 & 100 \\
\hline
\end{tabular}

Tabel 3 menunjukkan bahwa lama bekerja mayoritas responden sudah bekerja $\leq 10$ tahun yaitu sebanyak 28 responden $(63,6 \%)$, sudah bekerja $>10$ 
Vol. 11 No. 012020

e-issn : 2622-0148, p-issn : 2087-0035

tahun yaitu sebanyak 16 responden $(36,4 \%)$.

Gambaran Karakteristik Subyek Penelitian Berdasarkan Lama Bekerja per Hari

Tabel 4. Karakteristik Subyek Penelitian Berdasarkan Lama Bekerja per Hari

\begin{tabular}{ccc}
\hline Kategori & Frekuensi & $\begin{array}{c}\text { Persentase } \\
(\%)\end{array}$ \\
\hline $\begin{array}{c}\text { Durasi Singkat } \\
(<1 \text { jam })\end{array}$ & 3 & 6,8 \\
\hline $\begin{array}{c}\text { Durasi Sedang } \\
(1-2 \text { jam })\end{array}$ & 23 & 52,3 \\
\hline $\begin{array}{c}\text { Durasi Lama } \\
(>2 \text { jam })\end{array}$ & 18 & 40,9 \\
\hline Total & 44 & 100 \\
\hline
\end{tabular}

Tabel 4 menunjukkan bahwa frekuensi lama bekerja responden mayoritas berada pada kategori durasi sedang (1-2 jam) yaitu sebanyak 23 responden $(52,3 \%)$, durasi lama sebanyak 18 responden $(40,9 \%)$ dan durasi singkat sebanayak 3 responden $(6,8 \%)$.

\section{Gambaran Karakteristik Subyek Penelitian Berdasarkan Kejadian Low Back Pain}

Tabel 5. Karakteristik Subyek Penelitian Berdasarkan Kejadian Low Back Pain

\begin{tabular}{ccc}
\hline Kategori & Frekuensi & $\begin{array}{c}\text { Persentase } \\
(\%)\end{array}$ \\
\hline Tidak Terjadi LBP & 14 & 31,8 \\
\hline Terjadi LBP & 30 & 68,2 \\
\hline Total & 44 & 100 \\
\hline
\end{tabular}

Tabel 5 menunjukkan bahwa frekuensi kejadian Low Back Pain mayoritas responden berada pada kategori terjadi LBP yaitu sebanyak 30 responden $(68,2 \%)$, dan sebanyak 14 responden $(31,8 \%)$ berada pada kategori tidak terjadi Low Back Pain.

Analisis Hubungan Lama Bekerja Perhari Dengan Kejadian Low Back Pain Pada Pengrajin Sanggah (Pasir Hitam)

Tabel 6. Hasil Analisis Spearman Rank Test

\begin{tabular}{cccc}
\hline Spearman rank & N & r & p \\
\hline $\begin{array}{c}\text { Hubungan Lama Bekerja } \\
\begin{array}{c}\text { Perhari Dengan Kejadian } \\
\text { Low Back Pain }\end{array}\end{array}$ & 44 & 0.301 & 0.047 \\
\hline
\end{tabular}

Tabel 6 menunjukkan uji analisis menggunakan Spearman Rank Test di dapatkan hasil nilai $p$ value 0,047 yang berarti $<0,05$ sehingga ada hubungan yang sangat signifikan antara lama bekerja perhari dengan kejadian Low Back Pain pada pengrajin sanggah (pasir hitam) di Banjar Selat Tengah Susut Bangli.

\section{PEMBAHASAN}

Low Back Pain (LBP) merupakan rasa nyeri yang menyerang punggung bawah dengan gejala nyeri lokal, radikular, atau keduanya. Nyeri ini terasa pada lumbar atau lumbosakral dan sering disertai dengan nyeri ke arah tungkai dan kaki (Tanjung, 2009). Nyeri punggung bawah merupakan penyakit yang tidak mengenal usia dapat menyerang usia muda maupun usia tua yang sering terjadi dalam kehidupan sehari-hari (Widyastoeti, 2009). Berdasarkan penelitian dari Safitri (2010), penyebab dari Low Back Pain yang paling banyak dijumpai yaitu disebabkan oleh duduk yang terlalu lama, sikap duduk yang salah dan aktivitas yang terlalu berlebihan. Lamanya waktu bekerja dapat menyebabkan risiko terjadinya nyeri punggung bawah (Suma'mur, 2009). Posisi duduk baik tegak maupun membungkuk dalam jangka waktu lebih dari 30 menit dapat mengakibatkan gangguan pada otot (Risyanto, 2008).

Hasil penelitian ini menunjukkan bahwa ada hubungan lama bekerja per hari dengan kejadian low back pain pada pengrajin Sanggah (pasir hitam). Hal ini menunjukkan bahwa semakin lama seorang pengrajin Sanggah (pasir hitam) bekerja per hari maka berdampak pada semakin tingginya kejadian low back pain yang akan dialami.

Penelitian serupa yang dilakukan oleh Remon, Utami dan Dewi pada tahun 2015 mengenai hubungan antara posisi tubuh saat bekerja terhadap kejadian Low Back Pain pada petani sawit yang dilaksanakan di Kelurahan Kotalama. Penelitian ini membahas berapa umur petani sawit, lama masa kerja, jumlah sawit yang diangkat, gambaran posisi kerja saat bekerja terhadap kejadian low back pain. Hasil uji Chi-Square posisi tubuh dengan kejadian Low Back Pain diperoleh nilai $p$ value $0,000(p<0,05)$ yang menunjukkan bahwa ada hubungan yang signifikan antara posisi tubuh saat bekerja dengan kejadian Low Back Pain pada petani sawit.

Low Back Pain merupakan penyakit yang sering dijumpai dan menimbulkan banyak permasalahan. Dilihat dari data yang dikumpulkan dari penelitian Pusat Riset dan Pengembangan Pusat Ekologi Kesehatan, Departemen Kesehatan yang melibatkan 800 orang dari 8 sektor informal di Indonesia menunjukkan keluhan Low Back Pain dialami oleh 31,6\% petani kelapa sawit di Riau, 21\% pengrajin wayang kulit di Yogyakarta, 18\% pengrajin onix di Jawa Barat, 16\% penambang emas di Kalimantan Barat, 14,9\% pengerajin sepatu di Bogor dan $8 \%$ pengrajin kuningan di Jawa Tengah. Selain 
Vol. 11 No. 012020

e-issn : 2622-0148, p-issn : 2087-0035

itu, pengerajin batu bata di Lampung dan nelayan di DKI Jakarta yang menderita keluhan LBP masingmasing $76,7 \%$ dan $41 \%$ (Sakinah, 2013)..

\section{KESIMPULAN}

Kesimpulan penelitian ini terdapat hubungan lama bekerja per hari dengan kejadian low back pain pada pengrajin Sanggah (pasir hitam). Hal ini menunjukkan bahwa semakin lama seorang pengrajin Sanggah (pasir hitam) bekerja per hari maka berdampak pada semakin tingginya kejadian low back pain yang akan dialami. Oleh karena itu, penting bagi pengrajin untuk mengatur waktu bekerja per hari agar mengurangi kejadian low back pain.

\section{DAFTAR PUSTAKA}

Departemen, Pendidikan Nasional. (2008). Kamus Besar Bahasa Indonesia, edisi keempat, Jakarta: Gramedia Pustaka Utama.

Harianto. (2010). Buku ajar kesehatan kerja. Jakarta: EGC.

Potter \& Perry. (2010). Buku Ajar Fundamental Keperawatan Konsep, Proses, dan Praktik. Jakarta: EGC.

Risyanto. (2008). Pengaruh Lamanya Posisi Kerja Terhadap Keluhan Subyektif Low Back Pain pada Pengemudi Bus Kota di Terminal Giwangan. http://www.journal.Ull.ac.id

Safitri, A. I. (2010). Hubungan Lama Posisi Duduk Terhadap Nyeri Punggung Bawah Pada Pegawai Rental Komputer di Kentingan Surakarta [Skripsi]. Surakarta: Universitas Muhammadiyah Surakarta. Sakinah.(2013). Faktor yang berhubungan dengan keluhan nyeri punggung bawah pada pekerja batu bata di Kelurahan Lawawoi Kabupaten Sidrap. Suma'mur. (2009). Higiene

Perusahaan dan Kesehatan Kerja (HIPERKES). Sagung Seto. Jakarta.

Tanjung, R. (2009). Diagnosis dan penatalaksanaan nyeri punggung bawah di puskesmas. Diperoleh tanggal 28 Januari 2015 dari http://elearning-po.unp.ac.id/.

Tarwaka.(2010). Ergonomi Industri Dasar-Dasar Pengetahuan Ergonomi dan Aplikasi di Tempat Kerja. Press Solo. Surakarta.

Widyastoeti, R. D. (2009). Analisa pengaruh aktivitas kerja dan beban angkat terhadap kelelahan musculoskeletal. Gema teknik Vol 2: 28-29. 